\title{
Method Development of Simultaneous Estimation of Domperidone and Esomeprazole Using Spectrophotometry
}

\author{
Gunasekar Manoharan* \\ Chemistry Department, Faculty of Science, Jazan University, Al-Rawda District, Jazan, Saudi Arabia \\ *Corresponding Author \\ Gunasekar Manoharan
}

\section{Article History}

Received: 27.06.2019

Accepted: 16.07.2019

Published: 30.07 .2019

\begin{abstract}
A novel, simple, sensitive and rapid spectrophotometric method has been developed for simultaneous estimation of Domperidone and Esomeprazole. The method involved solving simultaneous equations based on measurement of absorbance at two wavelengths, $267 \mathrm{~nm}$ and $300 \mathrm{~nm}, \lambda_{\max }$ of Domperidone and Esomeprazole respectively. Beer's law was obeyed in the concentration range of $10-50 \mu \mathrm{g} / \mathrm{ml}$ for Domperidone for Esomeprazole $5-25 \mu \mathrm{g} / \mathrm{ml}$. The method was found to be precise, accurate, and specific. The proposed method was successfully applied to estimation of Domperidone and Esomeprazole in combined tablets form with good accuracy and precision. The suggested methods were validated according to International Conference of Harmonization (ICH) guidelines and the results revealed that; they were precise and reproducible. All the obtained results were statistically compared with those of the reported method, where there was no significant difference.
\end{abstract}

Keywords: Domeperidone, Esomeprazole, $\lambda_{\max }$, spectrophotometric method

\section{INTRODUCTION}

Domperidone (DM); 5-chloro-1-[1-[3-(2-oxo-2,3-dihydro-1H-benzimidazole-1-yl)propyl]]piperidin-4-yl]-1,3-dihydro- $\quad 2 \mathrm{H}$ benzimidazol-2-one, is used as an antiemetic and to suppress nausea and vomiting. Domperidone is indicated for treating symptoms associated with upper gastrointestinal motility disorders caused by chronic and sub-acute gastritis. It is a gastrointestinal emptying (delayed) adjuvant, a peristaltic stimulant and exhibits antiemetic properties. It can be used in patients with Parkinson's disease and is also found to be effective in the treatment of gastro paresis [1-2].

Esomeprazole magnesium trihydrate1 (ESO) is chemically bis(5-methoxy-2-[(S)-[(4-methoxy-3,5-dimethyl-2pyridinyl)methyl]sulfinyl]-1-H-benzimidazole-1-yl) magnesium tri-hydrate, a compound that inhibits gastric acid secretion [3]. Esomeprazole is cost effective in the treatment of gastric esophageal reflux diseases. Esomeprazole is the S-isomer of omeprazole, the first single optical isomer proton pump inhibitor, generally provides better acid control than current racemic proton pump inhibitors and has a favorable pharmacokinetic profile relative to omeprazole [4-5].

Combination of these two is used for the treatment of gastric esophagus reflux disease. A detailed survey of literature revealed the estimation of Esomeprazole by gas chromatographic method, UV spectrophotometric method, TLC and several HPLC methods [6-9]. Estimation of Domperidone included spectrophotometric methods, HPLC and HPTLC in dosage forms [10-13]. However, no references have been found for simultaneous determination of Domperidone and Esomeprazole in pharmaceutical formulations. In this work a successful attempt has been made to estimate two drugs simultaneously by spectrophotometric analysis.

\section{MATERIALS AND METHODS Chemicals}

The Domperidone and Esomeprazole powder reference standard (RS) was purchased from Sigma, Germany. The Pepdal-O marketed tablet form Domperidone $30 \mathrm{mg}$ and Esomeprazole $20 \mathrm{mg}$, manufactured and marketed by Kendall Pharma, purchased from Vellore, local Pharmacy, India. All chemicals used were of analytical reagent-grade quality and solvents were of spectroscopic grade. Distilled water was used throughout this work, was purchased from Merck. A Shimadzu UV/Vis spectrophotometer, model 1601

Copyright @ 2019: This is an open-access article distributed under the terms of the Creative Commons Attribution license which permits unrestricted use, distribution, and reproduction in any medium for non commercial use (NonCommercial, or CC-BY-NC) provided the original author and source are credited. 
(Japan) was employed with spectral bandwidth of $0.1 \mathrm{~nm}$ and wavelength accuracy of $\AA 0.5 \mathrm{~nm}$ with automatic wavelength correction with a pair of $3 \mathrm{~mm}$ quartz cells.

\section{Preparation of standard stock solution}

The standard stock solutions of both Domperidone and Esomeprazole were prepared separately by dissolving an appropriate amount of Domperidone and Esomeprazole in $100 \mathrm{ml}$ standard flask using $0.1 \mathrm{~m}$ Hydrochloric acid as the solvent to give a concentration of $1000 \mu \mathrm{g} / \mathrm{ml}$ of both substances. Further dilutions were made based on the required concentrations. These solutions were then used for the establishing the following parameters.

\section{Absorption maximum $\left(\lambda_{\max }\right)$}

The stock solutions were suitably diluted with $0.1 \mathrm{M}$ hydrochloric acid so as to contain $30 \mu \mathrm{g} / \mathrm{ml}$ of Domperidone and of $20 \mu \mathrm{g} / \mathrm{ml}$ of Esomeprazole respectively. These solutions were then scanned in the UV region between 400-200 $\mathrm{nm}$ and it was found that Domperidone exhibited $\lambda_{\max }$ at $267 \mathrm{~nm}$ and Esomeprazole exhibited $\lambda_{\max }$ at $300 \mathrm{~nm}$.

\section{Beers law concentration range}

The stock solutions were suitably diluted with $0.1 \mathrm{M}$ Hydrochloric acid to get concentration range from $10-50 \mu \mathrm{g} / \mathrm{ml}$ for Domperidone and $5-25 \mu \mathrm{g} / \mathrm{ml}$ of Esomeprazole. These solutions were then scanned on a UV spectrophotometer in the wavelength region of 400 - $200 \mathrm{~nm}$ and there absorbance were measured at their respective absorption maxima ( $\left.\lambda_{\max }\right)$. The calibration curve was determined for each of the drug independently by plotting the absorbance values against concentration. From the graph, it was found that Domperidone obeys Beer,s law between 10-50 $\mu \mathrm{g} / \mathrm{ml}$ and Esomeprazole obeys Beer.s law between 5-25 $\mu \mathrm{g} / \mathrm{ml}$. The regression analysis was carried out for the calibration graphs to find out correlation coefficient, Y-intercept and slope of regression line which estimates degree of linearity.

\section{Assay of tablet formulation}

20 tablets were weighted and finely powdered. An accurately weighed quantity of powder equivalent to about $15 \mathrm{mg}$ of Domperidone and $10 \mathrm{mg}$ of Esomeprazole was transferred to $25 \mathrm{ml}$ standard flask. The content of the flask was mixed with $0.1 \mathrm{M}$ Hydrochloric acid and shaken well to dissolve the active ingredients and then made up to the volume to the same solvent. The solution was filtered through a membrane filter. $4 \mathrm{ml}$ of the filtrate was dilute to $100 \mathrm{ml}$ with the same solvent to get the concentration of $100 \mu \mathrm{g} / \mathrm{ml}$ of Domperidone and $50 \mu \mathrm{g} / \mathrm{ml}$ of Esomeprazole. Further dilutions were made based on the required concentrations. The absorbance values of the sample were recorded at $267 \mathrm{~nm}$ and $300 \mathrm{~nm}$.

\section{RESULT AND DISCUSSION}

The UV spectra of Domperidone and Esomeprazole are presented in figure 1. The absorption maxima were at $267 \mathrm{~nm}$ and $300 \mathrm{~nm}$ for Domperidone and Esomeprazole. The data regarding the absorption values of both drugs are given in table 1 and 2. Obeyance to Beer's law was confirm by the linearity of the calibration curve of Domperidone and Esomeprazole, which are represented in figure 2. Domperidone showed linearity in the concentration range of $10-50 \mu \mathrm{g} / \mathrm{ml}$ and the Esomeprazole showed linearity in the concentration range of $5-25 \mu \mathrm{g} / \mathrm{ml}$. The data regarding calibration curves are given in table 1 and 2 . The overlying spectra for the linearity of Domperidone and Esomeprazole area represented in figure 3 and 4 . The quantitative estimation was carried out on the tablet formulation by taking concentrations of Domperidone $30 \mu \mathrm{g} / \mathrm{ml}$ and $20 \mu \mathrm{g} / \mathrm{ml}$ of Esomeprazole. The data regarding the quantitative estimation is given in table 3. The tablet formulation shows percentage purity value ranging from $99.50-100.10 \%$ w/w for the Domperidone and $99.90-100.30 \% \mathrm{w} / \mathrm{w}$ for Esomeprazole. The percentage deviation values of concentrations were found to lie between -1.4 to 0.2 for Domperidone and -0.1 to 0.2 for Esomeprazole.

The quantitative results obtained were subjected to statistical analysis to find out standard deviation, relative standard deviation and standard error values. The relative standard deviation values below $2 \%$ indicating the precision of the methodology and low standard error values show the accuracy of the method. The statistical data is given in table 4 . The LOD and LOQ were calculated and the values are given in table 5 .

The validation of the proposed simultaneous equation method was further confirmed by recovery studied. The recovery data is given in table 6 . This serves as a good index of accuracy and reproducibility of the study. The repeatability of the method was confirmed by repeating the assay procedure with three different concentrations of three replicates each. (The data is presented in table 7). The results obtained in repeatability test expresses the precision of the given method. 


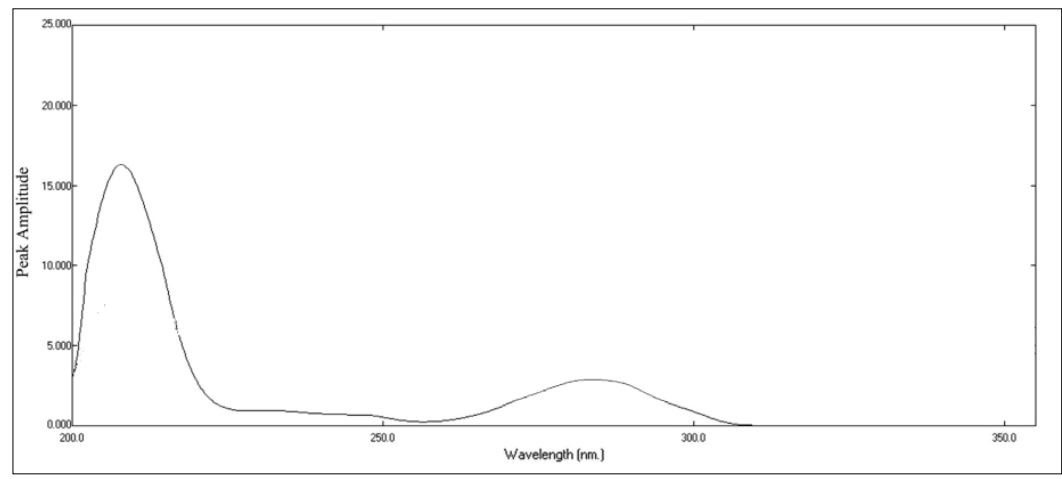

Fig-1: Absorption spectra of Domperidone and Esomeprazole

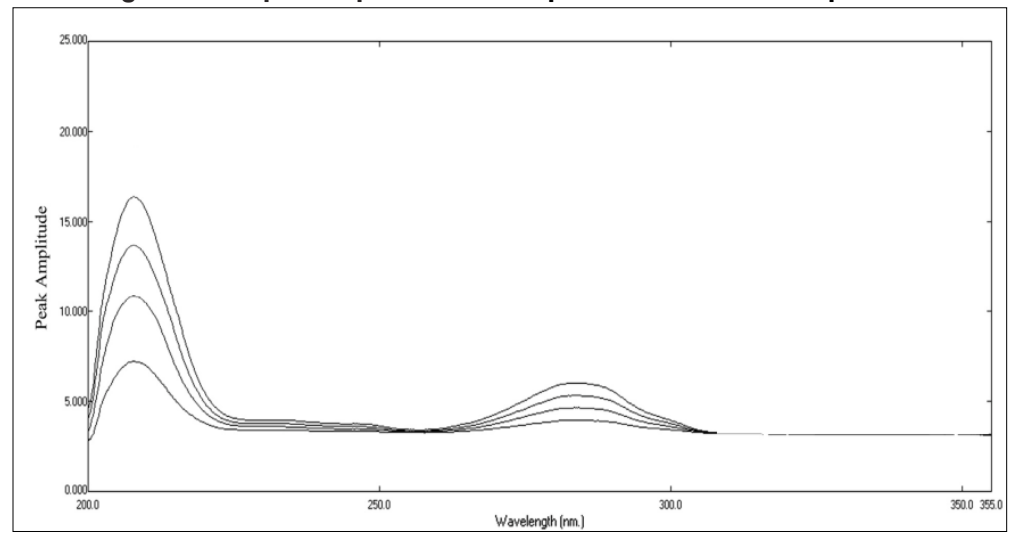

Fig-2: Overlying spectra of Domperidone and Esomeprazole

Table-1:Linearity data for Domperidone

\begin{tabular}{|l|l|}
\hline Concentration $(\boldsymbol{\mu g} / \mathrm{ml})$ & Absorbance \\
\hline 10 & 0.207 \\
\hline 20 & 0.403 \\
\hline 30 & 0.621 \\
\hline 40 & 0.818 \\
\hline 50 & 1.035 \\
\hline
\end{tabular}

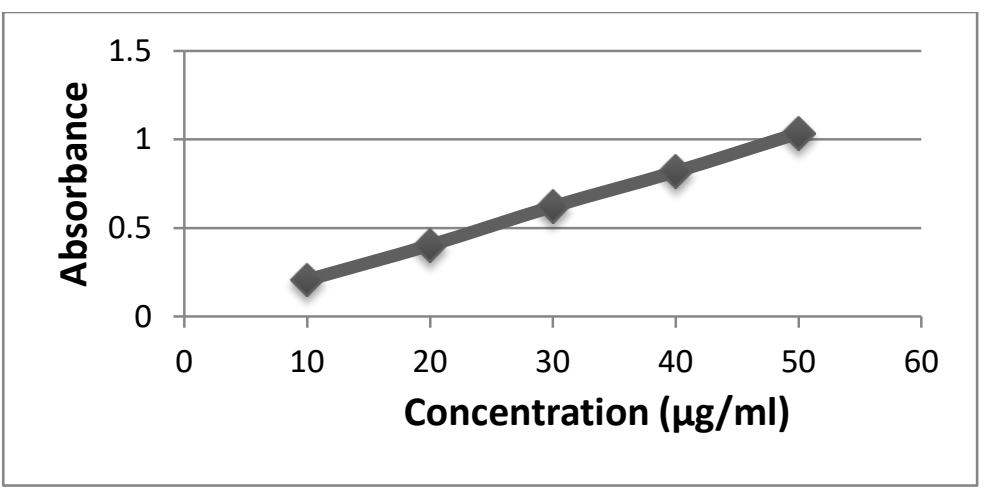

Fig-3: Calibration graph of Domperidone $10-50 \mu \mathrm{g} / \mathrm{ml}$ precision

Table-2: Linearity data for Esomeprazole

\begin{tabular}{|l|l|}
\hline Concentration $(\boldsymbol{\mu g} / \mathrm{ml})$ & Absorbance \\
\hline 5 & 0.189 \\
\hline 10 & 0.397 \\
\hline 15 & 0.557 \\
\hline 20 & 0.743 \\
\hline 25 & 0.953 \\
\hline
\end{tabular}




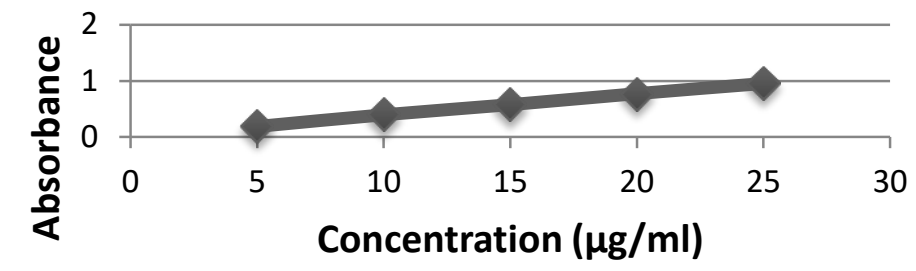

Fig-4: Calibration graph of Esomeprazole $5-25 \mu \mathrm{g} / \mathrm{ml}$ precision

Table-3: Quantitative estimaton of Domperidone and Esomeprazole (Assay) in tablets

\begin{tabular}{|l|l|l|l|l|}
\hline $\begin{array}{l}\text { Tablet } \\
\text { sample }\end{array}$ & $\begin{array}{l}\text { Lable claim } \\
\text { (mg/tablet) }\end{array}$ & $\begin{array}{l}\text { Amount } \\
\text { present } \\
\text { (mg/tablet) }\end{array}$ & $\begin{array}{l}\text { Percentage of } \\
\text { Lable } \\
\text { claim(\%w/w) }\end{array}$ & $\begin{array}{l}\text { Percentage } \\
\text { deviation }\end{array}$ \\
\hline Domperidone & 30 & 29.96 & 99.20 & -0.80 \\
\hline Esomeprazole & 20 & 20.21 & 100.19 & +0.19 \\
\hline
\end{tabular}

*Each value is a mean of six readings

Table-4: Stastistical data

\begin{tabular}{|l|l|l|l|l|}
\hline $\begin{array}{l}\text { Tablet } \\
\text { sample }\end{array}$ & $\begin{array}{l}\text { Standard } \\
\text { Deviation } \\
\text { (S.D) }\end{array}$ & $\begin{array}{l}\text { Relative } \\
\text { Standard } \\
\text { Deviation } \\
\text { (RSD) }\end{array}$ & $\begin{array}{l}\text { Relative } \\
\text { Standard } \\
\text { Deviation } \\
\text { (\%RSD) }\end{array}$ & $\begin{array}{l}\text { Standard } \\
\text { Mean error } \\
\text { (S.E) }\end{array}$ \\
\hline Domperidone & 0.006519 & 0.00627 & 0.627 & 0.0797 \\
\hline Esomeprazole & 0.0010 & 0.001048 & 0.1048 & 0.1311 \\
\hline
\end{tabular}

Table-5: Limit of detection and limit of quantiifcation

\begin{tabular}{|l|l|l|l|}
\hline S.No & Parameters & Domperidone & Esomeprazole \\
\hline 1. & $\operatorname{LOD}(\mu \mathrm{g} / \mathrm{ml})$ & 0.51 & 0.41 \\
\hline 2. & $\operatorname{LOQ}(\mu \mathrm{g} / \mathrm{ml})$ & 1.57 & 1.21 \\
\hline
\end{tabular}

Table-6: Recovery data of Domperidone and Esomeprazole tablets

\begin{tabular}{|c|c|c|c|c|c|}
\hline $\begin{array}{l}\text { Tablet } \\
\text { sample }\end{array}$ & $\begin{array}{l}\text { Amount } \\
\text { present in } \\
\text { preanalyzed } \\
\text { sample } \\
(\mu \mathrm{g} / \mathrm{ml})\end{array}$ & $\begin{array}{l}\text { Amount } \\
\text { of } \\
\text { standard } \\
\text { drug } \\
\text { added } \\
\text { ( } \mu \mathrm{g} / \mathrm{ml})\end{array}$ & $\begin{array}{l}\text { Amount } \\
\text { of drug } \\
\text { recovered } \\
(\mu \mathrm{g} / \mathrm{ml})\end{array}$ & $\begin{array}{l}\text { Percentage } \\
\text { recovery }\end{array}$ & $\begin{array}{l}\text { Mean } \\
\text { recovery } \\
\text { in } \%\end{array}$ \\
\hline Domperidone & 29.77 & $\begin{array}{l}30 \\
40 \\
50\end{array}$ & $\begin{array}{l}59.72 \\
70.01 \\
79.94\end{array}$ & $\begin{array}{l}99.50 \\
100.10 \\
99.91\end{array}$ & 99.80 \\
\hline Esomeprazole & 19.69 & $\begin{array}{l}15 \\
20 \\
25\end{array}$ & $\begin{array}{l}35.07 \\
40.12 \\
44.97\end{array}$ & $\begin{array}{l}100.2 \\
100.3 \\
99.98\end{array}$ & 100.2 \\
\hline
\end{tabular}

Table-7: Repeatability of assay procedures

\begin{tabular}{|c|c|c|c|c|c|c|c|c|}
\hline \multirow[t]{2}{*}{ Tablet } & \multicolumn{2}{|c|}{$\begin{array}{l}\text { Lable claim } \\
\text { (mg/ tablet) }\end{array}$} & \multicolumn{2}{|c|}{$\begin{array}{l}\text { Concentration } \\
(\mu \mathrm{g} / \mathrm{ml})\end{array}$} & \multicolumn{2}{|c|}{$\begin{array}{l}\text { Amount found } \\
\text { (mg/tablet) }\end{array}$} & \multicolumn{2}{|c|}{$\begin{array}{l}\text { Percentage label } \\
\text { Claim }(\% \mathrm{w} / \mathrm{w})\end{array}$} \\
\hline & $\begin{array}{l}\text { DO } \\
\text { MP }\end{array}$ & $\begin{array}{l}\text { ESM } \\
0\end{array}$ & DOMP & $\begin{array}{l}\text { ESM } \\
0\end{array}$ & DOMP & $\begin{array}{l}\text { ESM } \\
0\end{array}$ & DOMP & ESMO \\
\hline $\begin{array}{l}\text { Domp+E } \\
\text { som }\end{array}$ & 30 & 20 & 30 & 15 & 30.02 & 19.91 & 100.01 & 99.6 \\
\hline $\begin{array}{l}\text { Domp } \\
\text { +Esom }\end{array}$ & 30 & 20 & 40 & 20 & 29.97 & 20.01 & 99.97 & 100.1 \\
\hline $\begin{array}{l}\text { Domp } \\
\text { +Esom }\end{array}$ & 30 & 20 & 50 & 25 & 30.11 & 20.07 & 100.4 & 100.4 \\
\hline
\end{tabular}

${ }^{*}$ Each value is a mean of three readings 


\section{CONCLUSION}

The proposed methods were successfully developed for simultaneous estimation of Domperidone and Esomeprazole from their combined dosage form and found to be simple, precise, accurate, sensitive, and selective. It does not suffer from the interference of excipients. The methods were also extended to analyze the marketed formulations and results obtained are good agreement with label claim

\section{REFERENCES}

1. Martindale. (2002). The Complete Drug Reference, $32^{\text {nd }}$ edition. The Pharmaceutical press, $1209,1190$.

2. Malik, S. A., Malik, B. B., Gupta, R., Dhir. (2001). Indian Drug Review, March - April, VII, 23. MediWorld Publications Pvt. Ltd., New Delhi, 20.

3. British Pharmacopoeia Commission. (1993). British Pharmacopoeia 1993.

4. Pharmacopoeia, I. (1996). Controller of publications. New Delhi, 2, 764.

5. Scott, L. J., Dunn, C. J., \& Mallarkey, G. (2002). Esomeprazole: A review of its use in the management of acid-related disorders in the US (vol 62, pg 1091, 2002). Drugs, 62(15), 2183-2183.

6. Zarapkar, S. S., \& Salunkhe, B. B. (1990). Determination of domperidone by high performance thinlayer chromatography in pharmaceutical preparations. Indian drugs, 27, 537-40.

7. Yamamoto, K., Hagino, M., Kotaki, H., \& Iga, T. (1998). Quantitative determination of domperidone in rat plasma by highperformance liquid chromatography with fluorescence detection. Journal of Chromatography B: Biomedical Sciences and Applications, 720(1-2), 251-255.

8. Argekar, A. P., \& Shah, S. J. (1999). Simultaneous determination of cinnarizine and domepiridone maleate from tablet dosage form by reverse phase ion pair high performance liquid chromatography. Journal of pharmaceutical and biomedical analysis, 19(6), 813-817.

9. Zarapkar, S. S., \& Kanyawar, N. S. (2002). Simultaneous estimation of domperidone and omeprazole in pharmaceutical dosage by reverse phase high performance liquid chromatography. Indian drugs, 39(4), 217-221.

10. Li, X. Q., Andersson, T. B., Ahlström, M., \& Weidolf, L. (2004). Comparison of inhibitory effects of the proton pump-inhibiting drugs omeprazole, esomeprazole, lansoprazole, pantoprazole, and rabeprazole on human cytochrome P450 activities. Drug metabolism and disposition, 32(8), 821-827.

11. Shetty, R., Subramanian, G., Ranjith Kumar, A., Pandey, S., \& Udupa, N. (2005). Estimation of esomeprazole in human p_asma ey reverse phase high performance liouid chromatography. Indian Drugs, $42,3$.

12. Kobylińska, M., \& Kobylińska, K. (2000). High-performance liquid chromatographic analysis for the determination of domperidone in human plasma. Journal of Chromatography B: Biomedical Sciences and Applications, 744(1), 207-212.

13. Andersson, T., Hassan-Alin, M., Hasselgren, G., Röhss, K., \& Weidolf, L. (2001). Pharmacokinetic studies with esomeprazole, the (S)-isomer of omeprazole. Clinical pharmacokinetics, 40(6), 411-426. 